\title{
Strategi Gerakan Politik Keterlibatan: Tiga Pola Kerja Politik Aliansi Masyarakat Adat Nusantara (AMAN)
}

\section{Ernestus Lalong Teredi}

Lembaga Terranusa Indonesia

\begin{abstract}
Abstrak:
Kongres Aliansi Masyarakat Adat Nusantara (AMAN) yang diselenggarakan pada tahun 1999 merupakan momentum bangkitnya perjuangan masyarakat adat di Indonesia. Kebangkitan ini, disebabkan krisis dari berbagai kebijakan sebelumnya yang mengabaikan kehidupan masyarakat adat. Dari lanskap genealogi tersebut, tulisan ini memeriksa bagaimana dinamika dan strategi gerakan politik keterlibatan masyarakat adat di Indonesia. Tulisan ini menggunakan metode penelitian kualitatif dengan pendekatan analisis wacana. Temuan dalam tulisan ini, politik keterlibatan AMAN hadir karena krisis kebijakan yang tidak berpihak pada masyarakat adat. Mengisi krisis kebijakan tersebut, maka terdapat tiga pola politik keterlibatan AMAN yang dilakukan secara kontinu selama ini. Pertama keterlibatan akar rumput dengan tujuan menghidupkan kritisisme dan mengidentifikasi persoalan dalam kehidupan masyarakat adat. Kedua, ikut mengadvokasi kebijakan publik, yang bertujuan untuk menghadirkan kebijakan yang berpihak pada masyarakat adat. Ketiga, terlibat dalam pentas elektoral, dengan misi menghadirkan perwakilan yang paham persoalan dasar masyarakat adat. Dari keseluruhan temuan tersebut, benang merah yang dapat diambil yaitu pola gerakan politik keterlibatan AMAN berhasil membangun sikap kritis dan perlawanan dari komunitas masyarakat adat. Di sisi lain, gerakan politik keterlibatan AMAN mampu merumuskan kebijakan yang berpihak pada masyarakat adat serta mengutus kader ke jajaran politik struktural.
\end{abstract}

Keywords:

politik keterlibatan; krisis kebijakan; masyarakat adat

\section{Pendahuluan}

olitik berlangsung dalam dua ketegangan, yaitu kepluralitasan sosial
dan konflik. Demokrasi pun memberi legitimasi untuk mengelola
perbedaan dan konflik. Bahkan, lebih jauh, demokrasi memaksakan konflik politik agar permanen. Dalam demokrasi, yang paling dibutuhkan adalah keaktifan warga negara untuk memberi tuntutan politik. Demokrasi adalah ruang menjadikan warga negara untuk terlibat secara penuh dalam membingkaikan tentang

\footnotetext{
Korespodensi:

Lembaga Terranusa Indonesia, Jl. Saleh Abud No. 18-19, Otto Iskandardinata, Kp. Melayu, Jakarta Timur, 13330.

Email: ernestoterredi@terranusa.or.id
} 
kesejahteraan bersama. Keadilan dan kebaikan bersama akan tercapai ketika demokrasi meletakan warga negara sebagai penghuni dan pemandu jalannya negara. Dengan kata lain, demokrasi adalah kategori transendental (syarat kemungkinan) bagi tercapainya kebaikan bersama. Kira-kira itulah konsep politik keterlibatan yang menjadi acuan standar bagi negara demokratis. Yang artinya, adanya warga negara yang aktif 'demos' untuk selalu memberi tuntutan politik.

Tulisan ini berusaha melacak gerakan politik keterlibatan dari Aliansi Masyarakat Adat Nusantara (AMAN). Secara spesifik penulis akan memeriksa atas dasar apa munculnya politik keterlibatan tersebut. Di sisi lain, penulis akan menjelaskan tiga pola kerja politik keterlibatan dari AMAN; (I) gerakan akar rumput, (2) terlibat dalam mengadvokasi kebijakan publik baik di tingkat lokal pun nasional, (3) ikut dalam pentas elektoral. Secara ringkas, argumentasi dalam tulisan ini bahwa politik keterlibatan masyarakat adat muncul karena dislokasi atau krisis dari banalitas kebijakan yang mengabaikan masyarakat adat. Atau kebijakan negara, memiliki kecenderungan untuk menjalankan fantasi neoliberal - melalui regulasi serta menempatkan sektor sewasta sebagai pemandu kemajuan. Dalam moment krisis ini, pada akhirnya menghadirkan dimensi politis dari masyarakat adat untuk melawan melalui tiga pola yang menjadi kekuatan masyarakat adat yaitu politik keterlibatan.

Praktik politik keterlibatan masyarakat adat sebenarnya sudah menjadi suatu habituasi, dimana masyarakat adat sendiri mampu bertahan hidup, jauh sebelum negara ini terbentuk. Sehingga ketika masyarakat adat ditransformasi menjadi masyarakat Indonesia, tak serta merta dimensi keadatannya dihilangkan. Hal ini, bukan mempertegas soal esensialis identitas keadatan dari masyarakat adat. Melainkan mempertegas faktum pluralitas dari Indonesia sendiri. Sehingga menjaga faktum pluralitas tersebut, dalam Kongres Masyarakat Adat Nusantara pertama yang diselenggarakan pada Maret 1999, mensepakati mengenai siapa itu masyarakat adat melalui beberapa identifikasi baik secara partikular dan universal (Moniaga, 20I0; Sangaji, 20IO). Dan yang menjadi generik dalam konsep masyarakat adat adalah tentang wilayah adat yang mencakupi tanah adat, hutan adat, sosial, politik, ekonomi, hukum adat sampai kepercayaan masyarakat adat sendiri.

Kendati demikian, dinamika dari politik keterlibatan selama ini, muncul juga beberapa kritikan yang tajam dan hambatannya. Misalnya, konteks kerja akar rumput, yang hadir melalui program seperti pemberdayaan, pendidikan dan pelatihan - dalam momen ini, terjadinya pembentukan subjek masyarakat adat untuk dikontrol dan dinormalkan, atau dalam bahasa Li (2012) cara-cara tersebut sebagai teknikalisasi permasalahan. Dimana tujuannya untuk menjadikan masyarakat adat sesuai dengan tujuan dari para pejuang masyarakat adat. Singkatnya bahwa identifikasi persoalan itu muncul dari pegiat masyarakat adat, sehingga yang ditawarkanlah konsep pemberdayaan, dll. Kedua, dalam perjuangan politik elektoral tingkat lokal ataupun nasional, terkadang dari figur-figur yang diutus masyarakat adat mengalami persoalan 
yang besar. Hal ini dikarenakan politik lokal dilumati oleh praktik politik uang sebagai mana yang lazim terjadi dalam politik elektoral selama ini (Edward \& Sukmajati, 20I5). Serta bekerjanya watak bisnis atau yang dibahasakan sebagai rent seeking (Rahmawati, 2015: 99). Bahkan, parahnya terjadi keberjarakan antara kader masyarakat adat yang menang menjadi DPRD dengan basisnya yaitu komunitas masyarakat adat (Lies \& Dkk, 20I7).

Beragam problematisasi yang ada pada gerakan akar rumput harus diperiksa lebih dalam lagi. Jika diperiksa kritikan mengenai program atau gerakan akar rumput dan beberapa praktik busuk yang mendera praktik politik elektoral merupakan konteks praktis. Namun dalam konteks praktis tersebut, hal yang dilupakan adalah mengenai agenda-agenda alternatif dari partikular masyarakat. Dalam hal ini, kerja gerakan akar rumput yang dilakukan masyarakat adat, justru menghadirkan subjek masyarakat adat yang kritis dan radikal. Alih-alih penaklukan dan pendisplinan, justru masyarakat adat semakin masif dan kencang dalam melawan ketidakadilan yang mereka hadapi. Selain itu, kritikan yang memilahkan pejuang masyarakat adat dan masyarakat adat sebagai komunitas yang diberdayakan merupakan kritikan yang salah sasaran. Karena pejuang dan masyarakat adat merupakan satu kesatuan dalam bingkai Aliansi Masyarakat Adat Nusantara (AMAN). Sementara dalam konteks bekerjanya politik uang dan sektor swasta dalam mencari keuntungan, merupakan krisis dalam demokrasi sendiri yang sudah akut di Indonesia - dikarenakan absennya gerakan blok politik kritis. Terakhir adalah persoalan mengenai adanya keberjarakan antara masyarakat adat dan kadernya yang masuk dalam jajaran struktural politik. Problem seperti ini, rupanya lupa memeriksa bagaimana proses pengutusan kader dari masyarakat adat. Apakah diutus oleh komunitas atau maju untuk melayani fantasi keagenan dari kader sendiri.

Tulisan ini merupakan refleksi penulis sendiri selama terlibat dengan temanteman AMAN dalam rangka meneliti tentang Evaluasi Partisipasi Politik Masyarakat Adat Nusantara Pada Pemilu 2019, di Sumatera Utara (Deli Serdang), Sulawesi Selatan (Sinjai), Halmahera Tengah (Weda), Nusa Tenggara Timur (Sumba). Dan pada saat penulis melakukan penelitian tentang keterlibatan AMAN dalam Pembentukan Peraturan Daerah (Perda) yang berkaitan dengan masyarakat Adat di Bulukumba. Dalam penelitian ini, penulis mengacu pada posisi epistimologi dalam penelitian Ilmu Politik, melalui metode kualitatif yang memandang situasi sosial selalu diidentikan dengan pendekatan interpretatif, karena pada dasarnya sifat sosial sesuatu dinamis, terkonstruksi dan bertumbuhnya realitas sosial (Marsh \& Stoker, 20I2). Metode penelitian kualitatif menekankan pada teknik wawancara dan pengamatan, serta mencari refrensi pendukung temuan penulis sendiri. Kendati demikian, pendekatan yang dipakai dalam tulisan ini adalah analisis wacana atau discourse analysis. Tesis utama dari analisis wacana, setiap material empiris dan informasi merupakan objek atau subjek diskursif. Semuanya merupakan teks yang maknanya dibentuk dalam 
suatu diskursus tertentu. Konsekuensinya, semua data baik lingusitik maupun nonlinguistik dipikirkan sebagai suatu yang tidak netral, namun berada dalam suatu ruang makna yang siap untuk diperiksa melalui berbagai teknik, seperti dekonstruksi ataupun geneologi (Howarth \& Stavrakakis, 2000).

\section{Sekilas Konstruksi Teoritis}

Dalam beragam literatur, konsep politik keterlibatan merupakan suatu konsep yang jamak dalam politik kontemporer. Konsep politik keterlibatan merupakan derivasi dari gugus teori demokrasi. Sementara analisis wacana erat kaitan dengan konsep demokrasi radikal. Dalam tradisi demokrasi radikal yang dicetuskan oleh Laclau \& Mouffe (2008) sebuah tindakan dan praktik politik akan bermanfaat dalam ruang demokrasi untuk tujuan kebebasan dan kesetaraan. Aktivitas politik akan disebut berhasil, selama demokrasi mampu mengubah rakyat atau yang banyak menjadi 'demos' (warga negara yang aktif). Dengan kata lain, demos itu merupakan suatu hakikat politis dalam diri manusia melalui wicara, tindakan, dan karya (Hanna, I995; Riyadi, 2013). Wicara, tindakan, dan karya dijamin dalam demokrasi. Sehingga keterlibatan AMAN dalam berpolitik sebagai sinyal hidupnya 'demos' dalam memberi tuntutan politik itu sendiri.

Kendati demikian, tindakan dalam demokrasi radikal yang dicetus Laclau, bukan berbasis individualisme yang diagungkan oleh liberalisme. Tindakan sangat erat kaitan dengan kolektivitas. Ernesto (2005) \& Hanna (1995) menjelaskan bahwa, inti dari politik adalah solidaritas, untuk mencapai kolektivitas. Dengan adanya solidaritas, maka dengan sendirinya kepentingan bisa dinegosiasi dan tercapai. Demokrasi membiarkan kolektivitas itu tumbuh. Karena dengan tumbuhnya solidaritas dan kolektivitas, maka pelacakan serangkaian tentang kewargaan tidak hanya pada satu dimensi saja, melainkan justru membiarkan "sub-altern" bisa berbicara (Isin, 2002). Dengan berarti, demokrasi menjamim solidaritas dan kolektivitas untuk memunculkan keberpihakan dan memberi ruang bagi siapa saja untuk berbicara, termasuk kelompok marjinal.

Dalam kerangka pemikiran demikian, maka solidaritas merupakan salah satu basis dalam mengidentifikasikan soal identitas dalam masyarakat. Artinya, identitas menjadi penekanan penting dalam memahami demokrasi radikal. Ketika berbicara identitas, maka erat kaitan dengan subjek. Subjek dalam perspektif analisis wacana yang mana mengacu pada Lacan, merupakan subjek yang lack atau selalu berkekurangan dalam menentukan siapa dirinya (Stavrakakis, 2002). Dikatakan lack karena segala hal tentang subjek selalu mengalami rupture atau keterputusan secara permanen. Sehingga dalam momen lack, subjek selalu mengalami kontingensi - suatu keadaan yang masih diliputi ketidakpastian dan berada di luar jangkauan. Dari sinilah muncul apa yang dinamakan sebagai subject position atau posisi subjek dalam berbagai 
medan diskursif, serta political subjectivity yang menjelaskan tindakan dari subyek yang lahir dari kontingensi struktur-struktur diskursif (Stavrakakis, 2002).

Penjelasan mengenai subjek tersebut merupakan sebuah bingkai dalam memahami tentang bagaimana masyarakat adat bisa memiliki imajinasi agar terlibat dalam demokrasi untuk memberi artikulasi politik. Untuk menjawab pertanyaan tersebut, maka hal yang harus dipahami bahwa korpus sosial merupakan arena sebagai hadirnya aktus-aktus politik dalam membentuk solidaritas dan kolektivitas. Persis dalam momen ini, dengan membentuk kembali identitas dari masyarakat adat, merupakan sinyal adanya political subjectivity yang mana subyek lahir dari kontingensi struktur-struktur diskursif. Pada momen ini masyarakat melakukan sedimentasi dan reaktifasi, dan inilah yang dinamakan sebagai politikal. Namun dalam rekatifasi dan sedimentasi, secara permanen mengalami patahan atau kekurangan. Persis manusia, siapapun itu selalu berada dalam ketegangan yang permanen tersebut. Dengan berarti, perjuangan apapun itu inheren dilakukan tergantung konteks dan situasi yang membentuknya. Dan kepastian dari perjuangan tersebut selalu berproses tanpa selesai.

Dengan kata lain, membangkitkan imajinasi historis dari masyarakat adat bukan hanya mekanisme dalam membentuk solidaritas dan kolektivitas, karena hal ini sebenarnya permanen dalam tubuh sosial. Lebih jauh bahwa kebangkitan masyarakat adat merupakan momen politikal, akibat krisis dari struktur diskursif demokrasi liberal yang menekan pada individualisme, yang sebenarnya sangat kontradiksi dengan kehidupan sosial masyarakat adat sendiri. Sehingga inti dari tesis Ernesto (2005) mengenai politik keterlibatan, menekan pada identifikasi identitas. Namun dalam identifikasi tersebut subjek yang berada dalam satu identitas tidak pernah fix, karena ia akan selalu terbentuk dalam setiap dinamika sosial. Dalam konteks ini, bagi Mouffe dalam demokrasi, kewargaan bisa berkontribusi pada kebebasan dan kesetaraan dengan menggabungkan cita-cita dan pluralisme dengan ide-ide semangat publik dan kepedulian pada etika politik. Pada momen inilah hegemonik tercapai melalui rute demokrasi radikal.

Apa yang menjadi penjelasan di atas bahwa politik keterlibatan merupakan momen dimana subjek melakukan tindakan berdasarkan solidaritas dari pembentukan sosial. Tindakan, baik itu dalam bentuk perlawanan atau praktik apapun, yang mana bertujuan dalam menentukan artikulasi politik. Artinya politik keterlibatan hanya masuk dalam folder demokrasi, karena menekan pada solidaritas dan kolektivitas dan adanya identifikasi secara terus menerus yang tidak final. Pada titik ini, demokrasi akan bermanfaat ketika dijadikan ruang dalam menghadirkan praktik sosial. Singkatnya demokrasi harus dipraktikan berdasarkan fakta ontologi, yaitu dalam korpus sosial adanya ketegangan, solidaritas, kolektivitas dan identifikasi identitas secara terus menerus. 
Dengan demikian, politik keterlibatan masyarakat adat merupakan momen politikal, karena mereaktifasi keadatan dalam tubuh sosial untuk memberi artikulasi politik. Kendati sifatnya masih demonik karena belum mencapai dimensi hegemonik untuk mengikat setiap identitas sosial yang plural. Namun poin penting yang dipakai penulis dari argumen Laclau dan Mouffe adalah, soal kehadiran masyarakat adat untuk terlibat, karena efek dari krisisi. Sehingga suatu identitas mereaktifasi kembali identitas keadatan dalam rangka membentuk masyarakat untuk memberi artikulasi politik, yang mana hal ini sudah dirumuskan secara kolektif dalam tubuh masyarakat adat.

\section{Dislokasi dan Munculnya Politik Keterlibatan}

Hal yang paling penting diperiksa saat ini yaitu terkait munculnya politik keterlibatan. Secara ketat penulis merumuskan bahwa dislokasi atau nir-kebijakan yang tidak berpihak pada masyarakat adat, justru menghadirkan politik keterlibatan itu sendiri. Dengan kata lain, krisis dari tata kebijakan yang buruk, otomatis akan menghadirkan artikulasi politik dari masyarakat adat. Dalam konteks global momen dislokasi juga telah membangkitan gerakan politik masyarakat adat. Dari beberapa negara seperti di Afrika, Asia, Amerika Latin, kita belajar bagaimana kebangkitan masyarakat adat menjadi sangat politis, untuk melawan ketidakadilan karena kehilangan tanah dan kehancuran dignity. Gerakan masyarakat adat muncul kembali dalam berbagai konteks politik yang spesifik, disebabkan terus bekerjanya nalar kolonialisme melalui berbagai institusi negara kendati kolonialisme itu sudah berlalu, (Djalong, 20II).

Sementara dalam konteks Indonesia praktik yang sama dari neoliberal juga masih berjalan yaitu efek dari otoritarianisme Orde Baru (Orba) selama 30 tahun yang mengabaikan kehidupan masyarakat adat secara umum melalui mekanisme mengontrol akses hutan dan tanah. Efeknya pun sampai saat ini masih terdapat halhal seperti regulasi yang mengatur masyarakat adat untuk apolitis dan dijadikan objek pembangunan semata. Bukti nyatanya adalah bagaimana kekuatan sektor swasta untuk menguasai Sumber Daya Alam (SDA) di Indonesia saat ini masih masif dilaksanakan dan mengabaikan masyarakat adat sendiri.

Pada praktik yang paling spesifik dan subtil, yang terjadi hari ini dengan memperkuat sektor swasta dalam menguasai SDA, misalnya Lamonge (2012) dengan melacak khusus terhadap Perusahan Merauke Integrated Food \& Energy Estate (MIFEE) di Papua, temuanya bahwa paradigma neoliberalisme dan kebijakan pemerintah di Indonesia memberi legitimasi yang kuat bagi implementasi MIFFE. Hal ini diperparah dengan adanya upaya untuk mengontrol gerakan masyarakat adat supaya tidak melawan. Di sisi lain desain kebijakan dari negara juga memuluskan agenda neoliberal yang menyusup melalui kebijakan agraria di Indonesia (Ya'kub, 
2004). Singkatnya kebijakan yang dikeluarkan selain tidak berpihak pada masyarakat adat, teknik pendisplinan pada masyarakat adat juga terus dilakukan.

Selain kebijakan negara melalui sektor swasta dengan penegasan melalui aturan dalam konteks desain kebijakan. Hal yang tak kalah penting adalah neoliberal membangun polarisasi konflik antara masyarakat adat dengan kekuatan lain seperti dengan perusahaan dan negara. Berdasarkan data tahun 2018 terdapat 152 komunitas Masyarakat Adat yang menghadapi konflik dan sebanyak 262 warga Masyarakat Adat telah dikriminalisasi; ada yang berakhir di penjara dan ada yang berstatus sebagai Dafta Pencarian Orang (DPO). Kasus-kasus ini berkisar pada perampasan wilayah adat yang diikuti dengan tindakan kekerasan dan kriminalisasi (Catahu AMAN, 20I8). Discourse konflik pun sengaja diatur dan dirapikan sedemikian rupa, supaya masyarakat adat menjadi subjek dan objek kesalahan dari konflik. Narasi-narasi yang dikeluarkan semisalnya masyarakat barbarisme, pedalaman, melawan aturan negara, anti kemajuan, dll. Praktik demikian merupakan cara lama dalam setiap agenda neoliberal untuk membangun rasional pada publik serta men-sublim-kan dirinya sebagai sesuatu yang agung dan selalu benar. Padahal realitasnya, konflik tersebut karena adanya perbedaan kepentingan antara Pemerintah, Korporasi, dan masyarakat adat (Fringka, 20I7). Dan juga karena dominasi, marjinalisasi, degradasi ekologi, degradasi sosial budaya dan kemiskinan (Regus, 2015).

Dari penjelasan di atas, setidaknya kita dapat merumuskan ada tiga pola kerja dari negara dalam menjalankan kebijakan terhadap masyarakat adat. Pertama, membuat dan mengeluarkan regulasi, dalam pembentukan regulasi terjadinya pasal titipan atau riders. Dari sinilah sektor swasta ditempatkan sebagai otoritas pembangunan. Kedua, memberi keamanan bagi sektor swasta baik oleh aparatur negara dan diperkuatkan oleh regulasi. Ketiga, ketika terjadi perlawanan dari masyarakat adat, maka dengan sigap mengeluarkan statemen untuk mendelegitimasikan posisi masyarakat adat. Dari tiga hal ini, jika ditelusuri, bagaimana negara menjalankan fantasi dari konsep neoliberal misalnya dalam bentuk cara menguasai tanah atau Sumber Daya Alam (SDA) dari masyarakat adat dengan tiga tahap. Pertama, semua tanah yang tidak dapat dibuktikan kepemilikannya akan dikuasai oleh negara. Kedua, penetapan batas-batas tanah yang dinyatakan sebagai tanah dan/atau hutan negara adalah untuk menekan kontrol wilayah oleh pemerintah terhadap SDA tanpa memperhatikan apalagi menyelesaikan klaim pemegang hak atas tanah tersebut, termasuk masyarakat adat. Ketiga, setelah batas-batas sebuah wilayah ditetapkan, pemerintah akan menerbitkan izin pemanfaatan dan melarang siapapun untuk mengakses wilayah tersebut dan sumber daya alam di dalamnya, kecuali jika pemerintah mengizinkan (Komisi Nasional Hak Asasi Manusia, 20I6).

Dengan kata lain, setelah negara memiliki legitimasi melalui aturan karena masyarakat adat tidak memenuhi persyaratan dalam kepemilikan tanah dan pengelolaan SDA, maka otomatis masuknya sektor ketiga adalah sektor swasta. Cara 
kerja demikian merupakan bentuk akumulasi perampasan (accumulation by disposessession) (Harvey, 2005). Maksudnya, kerja agenda neoliberal saat ini tak hanya bekerja melalui reproduksi untuk mencari keuntungan semata, melainkan perampasan ruang hidup bagi kelompok rentan untuk menjauhkan aset-asetnya. Bukti empiris dalam bentuk akumulasi perampasan ini seperti kasus di Sumba Timur, terdapat salah satu perusahan yang membangun Perkebunan Tebu di bawah naungan PT. Muria Sumba Manise (MSM). Konsesi PT MSM, berada di atas tanah masyarakat, tanah ulayat, dan tanah pemerintah/negara yang selama ini sebagai wilayah padang savana penggembalaan ternak masyarakat setempat. Dampak terburuk masyarakat adat setempat telah kekurangan air minum, selain itu savana penggembalaan ternak hilang, serta kekurangan air bagi ternak-ternak.

Pola kerja penguasaan terhadap tanah dan SDA dari masyarakat adat di atas setidaknya menjelaskan dua hal kunci terkait bagaimana praktik negara neoliberal saat ini. Pertama, negara sebagai pengatur keamanan, pemegang dan pengendali legitimasi menggunakan seluruh kekuatan untuk menguasai tanah dan seluruh SDA dari masyarakat adat. Artinya ketika masyarakat adat tidak memiliki bukti yang kuat secara hukum, maka masyarakat adat dikatakan tidak sah terhadap kepemilikan tanah dan SDA yang ada di wilayah adat. Kedua, bentuk akumulasi perampasan dari negara dengan menempatkan sektor swasta sebagai pawang dan pemandu kemajuan. Dengan membiarkan sektor swasta yang berkuasa dan mengurus segalanya dan masyarakat adat menjadi penonton setia. Kritikan mendasarnya, dalam kerangka neoliberalisme, negara hadir dalam peran fasilitatif sedangkan kelompok swasta menjadi motor penggerak dalam pembangunan (Juru, 20II). Alhasil, kemiskinan menjadi permanen dalam kehidupan masyarakat adat. Atau dalam bahasa sederhana, kemiskinan dalam masyarakat adat bukan sesuatu yang alamiah, melainkan dibuatbuat.

\section{Tiga Pola Politik Keterlibatan Masyarakat Adat}

\section{Gerakan Politik Akar Rumput}

Dari penjelasan sebelumnya, absennya kebijakan yang berpihak pada masyarakat adat, memunculkan perlawanan dari masyarakat adat. Secara konseptual dan praktis, gerakan politik keterlibatan AMAN sebagai suatu kerja politik yang tersistematis. Sebab, hal yang dilakukan bukan berbasis spontanitas, sporadis dan momentum semata. Melainkan adanya suatu kerangka kerja politik dengan mengaitkan agenda yang satu dengan yang lainnya. Dalam konteks gerakan akar rumput terdapat beberapa dimensi yang penting untuk diketahui dimana itu hadir melalui program dari masyarakat adat sendiri. Program tersebut mencakupi; pemberdayaan, pelatihan, pendidikan. Uniknya, praksis dari gerakan akar rumput pun menjadi dasar dari segala dasar dalam politik keterlibatan lainnya. Dikatakan 
menjadi dasar, karena politik akar rumput menjadi dasar dari AMAN dalam membangun sikap kritis, keberpihakan, dan perlawanan.

Ada pun praktik politik akar rumput dari masyarakat adat yang penulis ringkas dengan keterbatasan antara lain; Pertama, pemberdayaan, hal ini dilakukan bukan untuk memberdayakan komunitas adat semata. Tetapi, pemberdayaan untuk memahami secara bersama terkait potensi-potensi yang ada dalam masyarakat adat. Dalam kerja pemberdayaan, tidak ada yang diberdayakan dan melakukan pemberdayaan. Tetapi, terdapat saling mengisi antara sesama masyarakat adat sendiri. Dalam momen ini, sharing pengalaman dan pengetahuan menjadi penting. Sehingga inti dari pemberdayaan adalah adanya belajar bersama secara kolektif satu komunitas adat untuk memetakan berbagai macam potensi adat. Potensi yang digalipun sangat beragam, karena mencakupi, wilayah adat, ekonomi, sistem kelembagaan adat (politik, sosial, hukum) dan nilai-nilai yang ada dalam kehidupan masyarakat adat. Kedua, pelatihan, bertujuan untuk meningkatkan kapasitas komunitas masyarakat adat dalam mengelolah hasil produksi dari masyarakat adat. Pelatihan ini teknisnya dengan bertukar pengetahuan sesama masyarakat adat sendiri, atau melakukan studi banding antara satu komunitas masyarakat adat dengan komunitas masyarakat adat lain. Teknik kerja pun misalnya pada penenun diberi pelatihan untuk selalu mengolah bahan-bahan mentah dasar, seperti pewarna, kapas, sampai pada pembuatan dengan kualitas yang tinggi. Selain itu pelatihan juga dalam rangka mengolah produksi kebutuhan primer, seperti ubi, beras, jagung, yang mana semua itu harus ditingkatkan agar terintegrasi dengan pasar-pasar lokal bahkan pasar nasional. Ketiga, pendidikan bertujuan agar masyarakat adat tidak ahistoris. Sehingga praktis dari pendidikan dengan menggali sejarah adat, memetaka wilayah adat, memahami hak-hak asal-usul dari masyarakat adat sendiri. Misi besar dengan berjalannya pendidikan, agar masyarakat adat mampu memahami secara imparsial mengenai masyarakat adat. Maksud dari pendidikan ini agar ketika setiap masyarakat adat terlibat dalam kebijakan publik sebagai stake holder memiliki argumen yang kuat dalam memberi tuntutan politik.

Dengan demikian, penjelasan mengenai gerakan akar rumput di atas jika dirumuskan secara sederhana, politik akar rumput, menghidupkan masyarakat adat menjadi 'demos'. Untuk menjadi demos, maka masyarakat adat harus memahami mengenai potensi-potensi yang ada dalam kehidupan mereka, seperti hutan adat, tanah adat, sampai produksi kebutuhan primer dari masyarakat adat sendiri, atau segala hal yang berkaitan dengan kedignitasan dari masyarakat adat. Dengan kata lain, keaktifan warga negara membutuhkan suatu proses dan membutuhkan suatu kerja politik praktis di akar rumput. Sehingga demokrasi dikatakan demokratis atau demokrasi menjadi hal yang transendental selama warga negara bisa ditransformasi menjadi demos dalam mengartikulasikan kepentingan demi misi kesejahteraan bersama. 
Dalam analisis lebih jauh, praktik keterlibatan di atas yang menjelaskan soal political subjectivity, yang mana subjek masyarakat adat berusaha mendefinisikan mengenai dirinya sebagai masyarakat adat. Hal inilah momen politikal, karena berusaha mengisi kealpaan negara dalam mengurus masyarakat adat. Jika dalam konsep negara mengurus masyarakat adat hanya soal mengurus pernak-pernik kesenian, maka aktivitas akar rumput dari Aliansi Masyarakat Adat Nusantara, justru melampaui pernak-pernik adat yaitu menjadi masyarakat adat yang memahami kepemilikan tanah adat, hutan adat dan secara keseluruhan dalam bingkai kedignitasan dari masyarakat adat sendiri.

\section{Terlibat Dalam Advokasi Kebijakan Kebijakan}

Sementara dalam keterlibatan AMAN mengadvokasi kebijakan publik, ada dua pola kerja. Kerja tersebut membutuhkan identifikasi persoalan akar rumput yang mana ini diperoleh dari perjuangan akar rumput. Di sisi lain memahami isu kebijakan, hingga pada penguasaan terhadap konten. Semua hal ini menjadi lazim dalam setiap advokasi kebijakan. Tujuan dari keterlibatan masyarakat adat adalah merumuskan dan menghasilkan kebijakan yang baik bagi masyarakat adat. Dengan mengadvokasi kebijakan, maka agenda-agenda neoliberal melalui negara dalam bentuk regulasi, harus diperdebatkan dan ditantang bahkan dilawan. Banyak rancangan kebijakan yang dihambat oleh negara karena masifnya keterlibatan masyarakat adat dalam rancangan kebijakan tersebut. Di sisi lain kebijakan tersebut sudah masuknya riders. Salah satunya sampai saat ini adalah soal Rancangan Undang-Undang Masyarakat Hukum Adat (RUU MHA).

Kendati RUU MHA belum terealisasikan saat ini oleh negara. Namun sejarah beberapa kebijakan dan regulasi baik skala nasional maupun lokal begitu banyak. Salah satunya ialah Putusan MK 35. Argumentasi dasar dari Putusan MK 35 tersebut adalah mengakui masyarakat adat sebagai "penyandang hak" (rights bearer) dan subjek hukum atas wilayah adatnya. Putusan tersebut memberikan pengakuan hukum bagi hutan adat yang sebelumnya diklaim penguasaannya oleh negara dan dialokasikan untuk beragam, baik untuk kepentingan produksi berskala industri maupun kepentingan konservasi yang menempatkan pelestarian lingkungan di atas keadilan sosial, (Siscawati, 20I4). Dengan kata lain MK 35 memberi sinyal positif bagi masyarakat adat yang mana status akan wilayah adatnya dipertegas.

Sementara dalam konteks lokal, terdapat banyak Perda Masyarakat Adat yang lahir oleh Pemerintah Daerah dikarenakan keterlibatan AMAN beserta pegiat masyarakat adat lainnya. Berdasarkan data yang dirilis oleh Arizona \& Simamora (20I7) terdapat 69 produk hukum daerah untuk Masyarakat Adat yang diterbitkan sejak bulan Mei tahun 2013 hingga Desember 20I6. Dalam penjelasan lebih lanjut, Epistema mengatakan bahwa dari segi sifatnya, produk hukum daerah untuk Masyarakat Adat dikelompokkan menjadi tiga, yakni pengaturan, penetapan dan 
kombinasi, yakni pengaturan dan penetapan dalam satu produk hukum daerah. Kendati demikian, dalam analisis yang penuh keterbatasan, logika dasar dari AMAN dan pegiat masyarakat adat lainnya dalam keterlibatannya merumuskan kebijakan, sebenarnya tetap sama yaitu, melindungi wilayah adat yang mencakupi, tanah, hutan, air, pengetahuan, kelembagaan adat, dll. Dimana semua itu menjadi suatu hal yang mengikat dalam masyarakat adat. Karena tak ada masyarakat adat tanpa tanah dan hutan sampai pengetahuan dan kepercayaan, juga sistem sosial.

Keterlibatanmasyarakat adat dalam perumusan kebijakan publik, tingkat nasional dan daerah, bukan hanya soal terlibat saja, melainkan memiliki agenda politik yang jelas. Jika dalam perjuangan akar rumput, sebagai upaya mengkondisikan masyarakat adat supaya kritis melawan ketidakadilan atau dalam bahasa penulis sebagai strategi melawan neoliberal. Maka politik keterlibatan dalam perumusan kebijakan publik juga memiliki agenda besar, yaitu mengatur secara tegas antara sektor swasta dan wilayah masyarakat adat. Serta mereposisi masyarakat adat sebagai warga negara yang sama dengan masyarakat lainnya. Tujuannya adalah adanya distribusi kebijakan bagi masyarakat adat, sekaligus tidak mengekang masyarakat adat dalam membangun kekuatan akar rumput dengan regulasi yang represif. Dalam beberapa Perda yang diperjuangkan oleh AMAN dan pegiat masyarakat adat selama ini. Terdapat beberapa argumentasi yang sebenarnya memberi sinyal dan menjelaskan, Perda tersebut untuk mengatur sikap dominatif dari sektor swasta sendiri .

\section{Berkontestasi dalam Pentas Politik Elektoral}

Dengan menyisah celah-celah kecil, dalam keterlibatan kebijakan publik yang berbasis litigasi, maka mengatasi ini dengan adanya agenda keterlibatan dalam politik elektoral. Pada konteks politik elektoral, terdapat beberapa kerja politik yang digarap secara simultan. Pertama mengutuskan kader agar terlibat penuh dalam politik elektoral mulai dari; Pemilihan Kepala Desa (Pilkades), Pemilihan Kepala Daerah (Pilkada), Pemilihan Umum (Pemilu). Tujuannya sederhana yaitu menempatkan kader yang memahami persoalan masyarakat adat secara imparsial untuk menyuarakan hak-hak masyarakat adat di jajaran pemerintahan. Kedua memasukan anggota adat ke dalam sistem Pemilu, seperti Komisi Pemilihan Umum (KPU) Badan Pengawas Pemilu (Banwaslu) sampai di tingkat Kelompok Penyelenggara Pemungutan Suara (KPPS), tujuannya adalah untuk menjaga suara dari kader masyarakat adat. Ketiga Membentuk Tim Pemantau Pemilu Independen, untuk mengawasi praktik Pemilu dan memberi update setiap perkembangan dari Pemilu.

Semangat mengutus kader dalam politik elektoral sekaligus ke sistem Pemilu tetap sama yaitu dalam rangka menghadirkan perwakilan yang memahami persoalan masyarakat adat. Sehingga ketika merumuskan kebijakan, tidak buta terhadap persoalan masyarakat adat. Hal ini dipertegas sebelum Pemilu 20I9, Sekjen AMAN 
kembali menegaskan misi keterlibatan AMAN bahwa "Partisipasi politik masyarakat adat kembali ditingkatkan di tahun 20I9, dengan mendorong ratusan kader terbaik, untuk terlibat dalam pemilu dan legislatif. Langkah perjuangan ini didasari pada fakta bahwa berbagai pelanggaran hak masyarakat adat disebabkan oleh karena hukum dan kebijakan yang disusun oleh orang-orang yang tidak memahami persoalan masyarakat adat".

Jika diperiksa historisitas keterlibatan AMAN dalam politik elektoral, setidaknya hampir satu dekade belakangan terbilang signifikan. Pada Pemilu 2009, AMAN mencatat 2I2 utusan politik terdaftar sebagai calon legislatif di berbagai tingkatan, melalui jalur partai maupun Independen. Pada Pemilu 20I4, AMAN mengintervensi kontestasi politik elektoral di 55 Kabupaten dan I8 Provinsi, melibatkan I9I utusan politik yang mengendarai ragam Partai Politik. Pasca rekapitulasi nasional KPU pada Mei 20I4, tercatat 36 caleg utusan dari masyarakat adat yang lolos menjadi anggota legislatif di DPRD Kabupaten/Kota, DPRD Provinsi, dan DPD RI. Sementara pada Pemilu tahun 20I9, AMAN mencoba memperbanyak kadernya untuk terlibat dalam politik praktis. Terdapat sebanyak I63 utusan politik masyarakat adat yang maju sebagai calon legislatif melalui I6 Partai Politik di semua tingkatan pencalonan; 6 Calon Anggota DPD RI, I2 Calon Anggota DPR RI, 27 Calon Anggota DPRD Provinsi dan II8 Calon Anggota DPRD Kab/Kota. Mereka terdiri dari I34 caleg laki-laki, 29 caleg perempuan dan 38 caleg berumur di bawah 35 tahun. Tersebar di 77 Provinsi dan 55 Kabupaten/Kota . Yang berhasil pun juga mencakupi angka 30-an. Dan ini merupakan suatu pencapaian dari gerakan masyarakat adat dalam keterlibatannya di pentas elektoral.

Dari data-data di atas, hal yang paling menarik adalah contoh keterlibatan masyarakat adat dalam Pemilu 2019 di Halmahera Tengah yang menjelaskan soal politik keterlibatan terbilang signifikan. Di Halmahera Tengah, terdapat kader masyarakat adat yang selalu menjadi garda terdepan dalam mendampingi dan mengadvokasi masyarakat adat di tingkat komunitas masyarakat adat. Ketika proses menuju Pileg 20I9, maka hampir setengah anggota masyarakat adat di suatu komunitas adat mengusungnya untuk ikut dalam Pemilu tingkat Kabupaten. Karena dipaksa dan dituntut terus oleh komunitas masyarakat adat, maka akhirnya kader masyarakat adat tersebut mencoba secara bersama mengumpul dan menampung seluruh ide dari masyarakat adat. Ketika tercapainya kesepakatan bersama, kader masyarakat adat tersebut memberanikan diri untuk maju, dan akhirnya mampu memenangkan pertarungan tingkat lokal. Hal yang sama juga terjadi di Sumba Timur, yaitu kader yang sering terlibat di akar rumput, akhirnya diusung oleh masyarakat adat dan meraup suara yang begitu besar . Dua cerita ini sebenarnya menjelaskan bahwa kekuatan gerakan masyarakat adat dalam mendorong kadernya terlibat dalam politik elektoral, tidak terlepas dari solidaritas dan intimasi dalam perjuangan di akar rumput. 
Sementara dalam dimensi mengutus kadernya untuk menjadi KPU, Bawaslu, KPPS, maka hampir ratusan anggota masyarakat adat diutus, imannya tetap sama, untuk menghalau jurus-jurus praktik busuk dari politik elektoral selama ini yang menjadi langgam dalam politik elektoral. Keterlibatan seluruh elemen masyarakat adat dalam institusi sistem Pemilu, hasil dari kesepakatan bersama organisasi. Kerjannya pun tetap mengikuti ritme berdasarkan regulasi yang ditetapkan oleh negara. Namun, poin penting dari keterlibatan mereka dalam institusi sistem Pemilu, ingin memastikan suara kader masyarakat adat berjalan mulus. Sekaligus pada saat pemilihan berlangsung, tidak ada intervensi pada pemilih masyarakat adat sendiri.

Apa yang menjadi penjelasan mengenai mengutus kader dalam Pemilu, masuk ke sistem Pemilu dan membentuk Tim Pemantau Pemilu Independen, bukan saja menjelaskan soal tinggi rendah, menang dan kalah. Namun hal tersebut menjadi sinyal penting, dalam menjalankan gerakan politik, dibutuhkan kerja yang tersistem. Sehingga politik keterlibatan yang dilakukan, bukan soal terlibat semu dalam konteks tubuh yang hadir. Melainkan ada ide kolektif yang konkritnya dalam bentuk mekanisme kerja, pola, rutinisasi. Dalam analisis wacana, rasionalitas pemilu hadir melalui sistem, regulasi, dan pendisiplinan individu untuk patuh agar terlibat dalam Pemilu. Dalam pengaturan itu tentu praktik-praktik yang busuk dari politik elektoral pun terjadi. Akan selalu kita rekami bersama melalui berbagai media selama ini semisal politik uang. Maka untuk membajak kerja sistem tersebut, dibutuhkan sikap dekonstruksi yaitu membangun alternatif, masuk ke sistem bekerja dengan cerdas, untuk memenangkan pertarungan itu sendiri.

\section{Dilema dan Transformasi}

Akan tetapi, dalam penelitian ini juga beberapa dilema secara konseptual dan praktis masih terjadi. Dilema bergerak di akar rumput seperti, krtisisme dan agensi subjek untuk sadar melawan tidak menyeluruh pada anggota masyarakat adat. Namun harus dimaklumi bahwa perjuangan memang membutuhkan waktu yang panjang. Dan tentu kita masih membutuhkan aktor-aktor kritis dalam mengorganisir masyarakat adat kedepannya. Sementara dalam kebijakan, beberapa hal yang sulit juga dinegosiasi yaitu jika di tingkat pemerintah baik nasional dan lokal sudah memiliki kepentingan sendiri seperti adanya riders. Sehingga stagnanisasi pembentukan kebijakan pasti juga terjadi. Hal yang ada di depan mata saat ini seperti RUU MHA yang sudah lama diperjuangkan oleh masyarakat adat.

Sementara dilema yang sangat besar adalah politik elektoral sendiri, salah satu pertanyaan kuncinya adalah mengapa demokrasi representasi selalu menghadirkan elit (Juru, 20II). Kritikan ini sebenarnya menjadi permanen untuk membongkar dilema demokrasi representasi. Karena dalam analisis wacana, identitas merupakan artikulasi diskurisif Laclau (2005) dalam arti, identitas seseorang selalu dibentuk oleh wacana sosial baik melalui bahasa, struktur, simbolik. Sehingga ketika 
seorang menjadi pejabat, maka identitasnya berubah juga, karena konstruksi pejabat yang diembaninya membentuk caranya dalam bertindak.

Cara mengatasi persoalan ini pun, penulis mengajak untuk kembali pada ilustrasi alegori gua Plato. Dalam kisah gua Plato, ada sebuah gua yang di dalamnya meringkuk para tawanan. Mereka menghadap ke bagian belakang gua dalam keadaan terikat sedemikian rupa hingga tak bisa memutar badan. Di belakang mereka, antara mereka dan pintu masuk terdapat api besar. Di antara api dan para tahanan itu terdapat jalan. Di jalan itulah berlalu lalang dan mondar-mandir orang-orang yang membawa pelbagai benda. Para tawanan itu hanya melihat bayang-bayang dari orang beserta benda yang lalu lalang itu. Mereka berpikir bahwa bayang-bayang itulah realitas sebenarnya, dan tak ada lain selain yang mereka lihat itu. Syahdan, salah satu di antara mereka bisa melepaskan diri. Ia berpaling dan mulai melihat realitas yang lain dari yang dilihatnya selama ini. Ia pun keluar dari gua dan melihat yang sebenarnya. Ia pun sadar bahwa orang, patung, dan benda-benda yang selama ini dilihatnya dalam bayang-bayang di dalam gua hanyalah semacam jiplakan dari yang sebenarnya di luar gua itu. Ia pun kembali ke dalam gua dan menceritakan hal itu kepada kawan-kawannya yang lain. Namun yang didapatkannya adalah ia dimarahi dan mereka tak mau memenuhi ajakannya untuk ikut keluar.

Ilustrasi alegori gua Plato menceritakan bahwa kehidupan politik kita memang seperti tawanan. Namun butuh suatu petunjuk untuk membawa para tawanan keluar dari gua itu sendiri. Keluar dari gua berarti melihat realitas dengan melibatkan diri dalam realitas itu sendiri. Dalam realitas yang mana tubuh sosial hidup, menghadirkan sikap kritis dan resistensi. Sehingga poin penting dari politik keterlibatan, keluar dari tawanan dan menjadi manusia politik. Menjadi manusia politik berarti melibatkan diri dalam merumuskan kebaikan bersama. Persis dalam kelemahan demokrasi liberal yang menekan pada representasi, maka penting untuk adanya diskursus agonistik, yang mana setiap partikular masyarakat memberikan artikulasi politik (Juru, 20II). Dalam arti keterlibatan menjadi penting untuk dilakukan secara kontinu. Kendati kerentanan menjadi elit hasil dari utusan kader masyarakat adat itu permanen, namun dengan mengkritiki dan mengevaluasi pada kader yang diutus juga, setidaknya bisa mengisi kelemahan tersebut.

\section{Penutup}

Dari seluruh penjelasan di atas, maka dapat disimpulkan bahwa politik keterlibatan masyarakat adat merupakan momen krisis karena nir tata kebijakan dari negara terhadap masyarakat adat. Atau dalam bahasa kalangan post-strukturalis, kebijakan di Indonesia untuk masyarakat adat selama ini cendrung melayani fantasi ideologi neoliberal. Karena bermain pada ranah pendisplinan dan menempatkan sektor swasta sebagai pawang kemajuan. Sehingga dalam krisis kebijakan tersebut, dislokasi menjadi momen kebangkitan gerakan masyarakat adat dalam memberi 
artikulasi politik melalui tiga kekuatan gerakan, yaitu politik akar rumput, mengadvokasi kebijakan publik dan terlibat dalam pertarungan elektoral. Yang mana tujuan dari politik keterlibatan tersebut adalah, mengisi krisis program kebijakan yang tidak tepat sasaran pada masyarakat adat, merumuskan agenda kebijakan publik yang berpihak pada masyarakat adat dan menghadirkan representasi yang paham secara imparsial mengenai masalah dari masyarakat adat sendiri.

Walaupun gerakan dari AMAN melalui tiga pola kerjanya terbilang baik, namun dilema, persoalan, juga selalu melekat. Sehingga mengatasi persoalan tersebut, maka AMAN harus lebih memasifkan agenda gerakannya dalam tiga pola kerja selama ini. Karena dengan cara demikian, krisis dalam beberapa pos kebijakan mulai dari tingkat desa sampai pusat bisa diatasi. Dengan demikian, gerakan politik keterlibatan masyarakat adat melalui tiga pola harus kontinu dilakukan di masa yang akan datang, serta peka dengan perkembangan dari masyarakat adat itu sendiri.

\section{Ucapan Terima Kasih}

Terimakasih kepada kolega penulis yang telah berbagi diskusi dan memberi masukan. Untuk penulisan artikel ini.

\section{Pendanaan}

Penulis tidak menerima bantuan pembiayaan atau dana untuk penelitian, kepenulisan (authorship), dan publikasi dari pihak manapun

\section{Daftar Pustaka}

Arizona, Y. M., \& Simamora, I. L. (20I7). Pengakuan Hukum Terhadap Masyarakat Adat: Tren Produk Hukum Daerah dan Nasional Pasca Putusan MK 35/PUU$\mathrm{X} / 2012$. Jurnal Outlook Epistema, Hlm, I-I2.

Catahu. (20I8). Senjakala Nawacita dan Masa Depan Masyarakat Adat. Liansi Masyarakat Adat Nusantara (AMAN).

Djalong, F. (20II). Manggaraian Indigeneity: The Poor, The Sacred, and Demos In PostReform Indonesia. Universitas Gajah Mada.

Edward, A., \& Sukmajati, M. (2015). Politik Uang di Indonesia: Patronase dan Klientelisme pada Pemilu Legislatif 2014 Yogyakarta. PolGov, Fakultas Ilmu Sosial dan Politik, Universitas Gadjah Mada, 20I5. Yogyakarta: PolPolGov, Fakultas Sosial dan Politik, Universitas Gadjah Mada.

Ernesto, L. (2005). On Populist Reason. London: Verso.

Fringka, Y. (2017). Resistensi Berbasis Adat: Perlawanan Masyarakat Nagari III Koto, Tanah Datar, Sumatera Barat, Terhadap Rencana Tambang Bukit Batubasi. MASYARAKAT: Jurnal Sosiologi, 205-23I.

Hanna, A. (1995). Dimension of Radical Democracy, Pluralism, Citizhensip, Community. In Chantal Mouffe (Maurizio,). Verso. 
Harvey, D. (2005). A Brief History of Neoliberalism. Oxford: OXFORD University Press. Howarth, D., \& Stavrakakis, Y. (2000). Introducing Discourse Theory and Political Analysis.

Isin, E. F. (2002). Being Political: Genealogies of Citizenship. U of Minnesota Press.

Juru, I. J. (20II). Dislokasi Wacana Kewarganegaraan Melampaui Liberalisme Menuju Wacana Agonistik. Universitas Gadjah Mada.

Laclau, E., \& Mouffe, C. (2008). Hegemoni dan Strategi Sosialis: Post Marxisme dan Gerakan Sosial Baru. Yogyakarta: Resist Book.

Lamonge, M. (20I2). Neo-liberalism, Social Conflict and Identity of Papuan Indigenous People. Case study of Merauke Integrated Food \& Energy Estate (MIFEE) in Papua. Master thesis, International Institute of Social Studies, Erasmus University ....

Li, T. M. (20I2). The Will to Improve: Perencanaan, Kekuasaan, dan Pembangunan di Indonesia. Marjin Kiri.

Lies, M., \& Dkk. (2017). Dialog Demokrasi: Kembali ke Masyarakat Sipil? Jurnal Prisma, 36(I).

Marsh, D., \& Stoker, G. (2012). Teori dan Metode Dalam Ilmu Politik. Bandung: Nusa Media.

Moniaga, S. (2010). Dari Bumiputera ke Masyarakat Adat: Sebuah Perjalanan Panjang dan Membingungkan. Dalam Adat Dalam Politik Indonesia, Disunting Oleh JS Davidson, D. Henley, Dan S. Moniaga, 30I-322.

Komnasham, I. (2016). Hak Masyarakat Hukum Adat atas Wilayahnya di Kawasan Hutan. Jakarta: Komisi Nasional Hak Asasi Manusia Republik Indonesia.

Rahmawati, D. (2015). Demokrasi dalam Genggaman Para Pemburu Rente (Studi Kasus Asahan Sumatera Utara). Jurnal Ilmiah Ilmu Pemerintahan, I(2), 86-IO2. Retrieved from https://ejournal2.undip.ac.id/index.php/jiip/article/view/I623

Regus, M. (2015). Tambang dan Perlawanan Rakyat: Studi Kasus Tambang di Manggarai, NTT. MASYARAKAT: Jurnal Sosiologi, I-25.

Riyadi, E. (2013). Manusia Politik: Sebuah Rekonstruksi Interpretasi Hanna Arendt Terhadap Tindakan Politik Manusia. In Manusia, Perempuan, Laki-Laki. Jakarta: Salihara.

Sangaji, A. (20I0). Kritik Terhadap Gerakan Masyarakat Adat di Indonesia. Dalam Adat Dalam Politik Indonesia, Disunting Oleh JS Davidson, D. Henley, Dan S. Moniaga, 347366.

Stavrakakis, Y. (2002). Lacan and the Political. Routledge.

Ya'kub, A. (2004). Agenda Neoliberal: Menyusup Melalui Kebijakan Agraria Di Indonesia. Jurnal Analisis Sosial, 47-64.

\section{Tentang Penulis}

Ernestus Lalong Teredi adalah peneliti di Lembaga Terranusa Indonesia. 